\title{
Sensory analysis of textiles: case study of an assortment of stretch denim fabrics
}

DOI: $10.35530 / I T .070 .04 .1697$

\section{REZUMAT - ABSTRACT}

\section{Analiza senzorială a produselor textile. Studiu de caz al unui sortiment de țesături denim stretch}

În strategia de a îmbunătăți colecțiile de îmbrăcăminte ca o reacție la schimbările pieței de consum, producătorii de ţesături sunt conștienți de faptul că pe lângă profilul calitativ al țesăturilor este necesară asigurarea unui confort senzorial, care este dependent exclusiv de percepția personală a cumpărătorilor. Acest studiu se referă la evaluarea subiectivă a proprietăților tactile ale unui sortiment de șaptezeci de țesături denim tip stretch, produse din șapte articole create ca bază în faza de țesere. Cu două tipuri de legături diagonal, având fire din bumbac 100\% ca urzeală și, respectiv, șase variante de fire tip bumbac cu componentă de elastan ca bătătură, țesăturile crude au fost supuse la diverse combinații din șase procedee de pre-finisare și patru tehnici de spălare. S-au respectat îndrumările standardelor privind analiza senzorială ca test descriptiv, cu o singură excepție: panelul a fost constituit din șaisprezece evaluatori fără experiență. Analiza statistică a volumului de date a fost efectuată prin instrumentele interactive de învățare, STAT-Hand și STAT-ConCor, dezvoltate anterior studiului. Rezultatele au confirmat diverse modificări ale confortului senzorial al țesăturilor, prin intermediul a șase atribute senzoriale bipolare, evaluate ca descriptori ai acestuia. Deoarece aceste schimbări ale confortului senzorial au fost percepute de către evaluatori naivi, se poate miza pe faptul că și potențialii cumpărători de jeans confecționați din gama sortimentală de denim tip stretch vor putea percepe aceste diferențe, deși sunt evaluatori fără experiență în analiza senzorială. În acest context, țesătorii vor putea miza pe un feedback corect asupra efortului lor de a îmbunătăți permanent confortul senzorial al țesăturilor.

Cuvinte-cheie: evaluatori, analiză senzorială, confort senzorial, denim tip stretch, proprietăți tactile

\section{Sensory analysis of textiles: case study of an assortment of stretch denim fabrics}

The manufacturers, in their strategy to expand the garment collections, as a prompt reaction to the global market changes, are aware that the sensorial comfort is of the utmost importance, next to the quality profile of fabrics, and depends on the personal perception of purchasers. This research focused upon the sensory assessment of the tactile properties of an assortment of seventy stretch denim fabrics produced from seven articles in the loom-state phase. By combining two types of right-hand twill, with $100 \%$ cotton yarns in the warp and six mixture types as core-spun yarns in the weft, the fabrics were subjected to six pre-finishing processes and subsequently, to four washing techniques. The standards' guidelines on conducting the sensory analysis trials as descriptive tests were respected, with one exception: the panel consisted of sixteen assessors without experience. The statistical analysis of the extensive amount of sensory data was approached by the interactive ICT-based learning tools previously developed STAT-Hand and STAT-ConCor. The results showed changes in the six bipolar sensory attributes, as fabric hand descriptors, for the wide range of stretch denim fabrics. Since these changes of the sensorial comfort were perceptible for a panel of naive assessors, the potential stretch denim jeans' purchasers could also notice them. Therefore, this could be a good strategy for denim manufacturers to get the right feedback in their effort to continuously upgrade the fabrics sensorial comfort.

Keywords: assessors, sensory analysis, sensorial comfort, stretch denim, tactile properties

\section{INTRODUCTION}

Considered a specific niche, women's clothing is strongly influenced by trends in colors, pattern and fashion but also by the feelings about an adequate durability, a satisfactory degree of comfort in wearing and finally, yet importantly, a great aesthetic appearance, no matter what is the end use [1-3]. When the garment quality for women is defined from the weaving companies' perspective, there is a focus on the overall features that can be measured in a laboratory [4-5]. Predicting the overall suitability for designed end use and the products' success on the market can be a hard topic for fabrics and clothing manufacturers and for retailers, thus, the improving of the fabric design strategy should be a mandatory task in textile companies [3, 6-8]. A major concern within the textile value chain is to react timely to the consumer preferences and, nowadays, the sensorial comfort of any item of clothing together with the fabric quality seems to come first in the top of the consumer preferences. Regardless of the reference source and the market niche, polls about the clothing consumer lifestyle revealed that when shopping for apparel, consumers are not simply pursuing the latest fashion trends. On the contrary, they are willing to pay more for comfort, general appearance, and high-quality products, more 
than for any other designed features to cover consumers' value expectations [1-3]. This trend was found similar for the denim market, irrespective of segmentation (by product, by consumer type). Moreover, as consumers are becoming more concerned with health and exercise, and both professional and social dress codes are relaxing nowadays, the denim designers and manufacturers realized they needed to compete against athleisure apparel, which has the comfort factor in its side. To support this trend, the jeans manufacturers are innovating and adapting their products by pursuing the consumer demands, including by means of a wide range of finishing techniques carried out in different stages, as pre-finishing and washing processes. In addition, the denim global market landscape essentially changed with the appearance of more comfortable jeans, manufactured from stretch denim fabrics. By default, the stretch denim should have a degree of body fitting and should be more comfortable than the regular denim fabric, even if incorporating a small amount of elastane, and this fact should be proved by means of analysis of the fabrics sensorial comfort features [4-5].

In textiles, the sensory analysis approached as a subjective assessment technique is considered a usual practice for clothing sensorial comfort evaluation, pursuing the upgrading of the design stage for both fabrics and garments [6-10]. Recently, the sensory analysis was applied with good results to assess the comfort of functional fabrics for smart clothing [11]. However, in practice, the sensory analysis of inprocess and finished fabrics should be considered by implementing a sensory analysis programme into quality control [12]. This is because when buying an item of clothing, the consumers (with or without a background in textiles) tend to handle it so they can get a feeling on the fabric's quality and on the sensorial comfort they could benefit from, while wearing the garment [3, 7, 13].

To the best of our knowledge, the sensory analysis of the stretch denim fabrics hand has not yet been addressed. This paper aims to be a contribution to this topic by focusing on the evaluation carried out with a panel of naive assessors, who may be considered as almost untrained customers.

\section{MATERIALS AND METHODS}

\section{Materials}

In this study, a range of stretch denim fabrics, produced on PICANOL OMNI PLUS 800 air jet weaving machines, were chosen for sensory analysis of the tactile properties considering the similarities in manufacturing and final use, as jeans for women. Regarding the percentage of elastane used in the weft yarns, three variants were considered and also, the mixture with polyester next to the elastane asa suitable choice for weaving the stretch denim (table 1). Within the respect of the wide range of possible finishing treatments in denim manufacturing, a variety of pre-finishing treatments were applied in this research for the seven loom-state fabrics and, subsequently, different washing techniques (commonly used in garment industry for washing denim garments). Hence, seventy stretch denim fabrics were produced (half as greige denims and half as finished denims).

Details of the pre-finishing processes applied to the loom-state fabric to obtain the "greige" stretch denim (G01 to G35) are briefly described in table 2. It also describes the washing processes applied in order to obtain an appearance and properties as close as possible to those required by the jeans to be made of these materials, thus achieving the "finished" stretch denim (F01 to F35). Altogether, the labeling of the seventy stretch denim fabrics (greige/finished) was decided in view of the consumers' perception, when they are shopping for jeans.

\section{Techniques for sensory analysis as subjective evaluation of fabric hand}

The evaluation procedure AATCC [14] describes guidelines to assess the tactile properties of textiles by means of human perception of specific sensory attributes, as fabric sensorial comfort descriptors. In addition, approaching the topic of stretch denim fabric hand sensory evaluation, the main requirements on conducting the sensory analysis trials [15-20] showed some particularities in this paper, as follows.

\begin{tabular}{|c|c|c|c|c|c|c|c|c|}
\hline \multicolumn{9}{|c|}{ MAIN FEATURES OF DESIGNED STRETCH DENIM FABRICS IN THE LOOM-STATE PHASE } \\
\hline \multirow{2}{*}{$\begin{array}{l}\text { Article } \\
\text { code }\end{array}$} & \multicolumn{2}{|c|}{ Fabric composition } & \multirow{2}{*}{$\begin{array}{c}\text { Weave } \\
\text { structure }\end{array}$} & \multicolumn{2}{|c|}{$\begin{array}{c}\text { Yarn linear } \\
\text { density (tex) }\end{array}$} & \multicolumn{2}{|c|}{$\begin{array}{l}\text { Thread count } \\
\text { (yarns } / 10 \mathrm{~cm} \text { ) }\end{array}$} & \multirow{2}{*}{$\begin{array}{c}\text { Mass per } \\
\text { unit area } \\
\left(\mathrm{g} / \mathrm{m}^{2}\right)\end{array}$} \\
\hline & Warp & Weft & & Warp & Weft & Ends $/ 10 \mathrm{~cm}$ & Picks $/ 10 \mathrm{~cm}$ & \\
\hline SD1 & $100 \% \mathrm{CO}$ & $99 \% \mathrm{CO} / 1 \% \mathrm{EL}$ & 3/1 twill & 57 & 63 & $265 \pm 10$ & $200 \pm 10$ & $312 \pm 16$ \\
\hline SD2 & $100 \% \mathrm{CO}$ & $98 \% \mathrm{CO} / 2 \% \mathrm{EL}$ & $3 / 1$ twill & 57 & 63 & $270 \pm 10$ & $200 \pm 10$ & $317 \pm 16$ \\
\hline SD3 & $100 \% \mathrm{CO}$ & $98 \% \mathrm{CO} / 2 \% \mathrm{EL}$ & 2/1 twill & 65 & 33 & $257 \pm 10$ & $170 \pm 10$ & $257 \pm 13$ \\
\hline SD4 & $100 \% \mathrm{CO}$ & $92 \% \mathrm{CO} / 8 \% \mathrm{EL}$ & 2/1 twill & 42 & 42 & $250 \pm 10$ & $190 \pm 10$ & $207 \pm 10$ \\
\hline SD5 & $100 \% \mathrm{CO}$ & $92 \% \mathrm{CO} / 7 \% \mathrm{PES} / 1 \% \mathrm{EL}$ & $2 / 1$ twill & 76 & 37 & $240 \pm 10$ & $205 \pm 10$ & $314 \pm 16$ \\
\hline SD6 & $100 \% \mathrm{CO}$ & $85 \% \mathrm{CO} / 13 \% \mathrm{PES} / 2 \% \mathrm{EL}$ & $2 / 1$ twill & 76 & 33 & $220 \pm 10$ & $190 \pm 10$ & $280 \pm 14$ \\
\hline SD7 & $100 \% \mathrm{CO}$ & $77 \%$ CO $/ 22 \%$ PES/1\% EL & $2 / 1$ twill & 33 & 17 & $390 \pm 10$ & $250 \pm 10$ & $198 \pm 10$ \\
\hline
\end{tabular}




\begin{tabular}{|c|c|c|c|c|c|c|}
\hline \multicolumn{7}{|c|}{ PRE-FINISHING AND FINISHING PROCESSES APPLIED TO FABRICS IN LOOM-STATE PHASE } \\
\hline $\begin{array}{c}\text { Stretch } \\
\text { denim } \\
\text { (loom-state) }\end{array}$ & $\begin{array}{c}\text { Industrial } \\
\text { pre-finishing } \\
\text { process }^{*}\end{array}$ & $\begin{array}{l}\text { Greige } \\
\text { fabrics } \\
\text { codes }\end{array}$ & $\begin{array}{l}\text { Expected appearance effects } \\
\text { on fabrics surface }\end{array}$ & $\begin{array}{l}\text { Washing } \\
\text { techniques } \\
\text { (finishing) }\end{array}$ & $\begin{array}{c}\text { Finished } \\
\text { fabrics } \\
\text { codes }\end{array}$ & $\begin{array}{l}\text { Expected } \\
\text { appearance } \\
\text { effects on } \\
\text { fabric surface }\end{array}$ \\
\hline SD1 & \multirow{3}{*}{$\begin{array}{l}\mathrm{B} \rightarrow \mathrm{Si} \rightarrow \mathrm{C} \rightarrow \\
\mathrm{D} \rightarrow \mathrm{Sf} \rightarrow \mathrm{Ac} \rightarrow \\
\mathrm{So} \rightarrow \mathrm{D} \rightarrow \mathrm{Sf}\end{array}$} & G01 & Lustrous surface, leather effect & \multirow{3}{*}{$\begin{array}{l}\text { Light rinse for } \\
\text { coating shine }\end{array}$} & F01 & \multirow{3}{*}{$\begin{array}{l}\text { To protect the } \\
\text { coating and to } \\
\text { give an extra } \\
\text { shine effect }\end{array}$} \\
\hline \multirow{2}{*}{ SD2 } & & G02-G14 & Matt surface effect & & F02-F14 & \\
\hline & & G15-G18 & Semi-lustrous surface effect & & F15-F18 & \\
\hline SD2 & $\begin{array}{l}\mathrm{B} \rightarrow \mathrm{Si} \rightarrow \mathrm{C} \rightarrow \\
\mathrm{D} \rightarrow \mathrm{Sf} \rightarrow \mathrm{Rt} \rightarrow \\
\mathrm{So} \rightarrow \mathrm{D} \rightarrow \mathrm{Sf}\end{array}$ & G19-G21 & $\begin{array}{l}\text { Anti-crease and soft surface } \\
\text { effect }\end{array}$ & \multirow{2}{*}{$\begin{array}{l}\text { Enzyme } \\
\text { washing to } \\
\text { imitate stone } \\
\text { washing }\end{array}$} & F19-F21 & \multirow{2}{*}{$\begin{array}{l}\text { To achieve a } \\
\text { lightly worn and } \\
\text { faded look }\end{array}$} \\
\hline $\begin{array}{l}\text { SD2 } \\
\text { SD4 }\end{array}$ & $\begin{array}{l}\mathrm{B} \rightarrow \mathrm{Si} \rightarrow \mathrm{C} \rightarrow \\
\mathrm{D} \rightarrow \mathrm{Sf}\end{array}$ & $\begin{array}{l}\text { G22-23; } \\
\text { G28-29 }\end{array}$ & $\begin{array}{l}\text { Shinier look, a fuller appear- } \\
\text { ance and a more intense and } \\
\text { regular shade }\end{array}$ & & $\begin{array}{l}\text { F22-23; } \\
\text { F28-29 }\end{array}$ & \\
\hline $\begin{array}{l}\text { SD2 } \\
\text { SD3 }\end{array}$ & $\begin{array}{l}\mathrm{B} \rightarrow \mathrm{Si} \rightarrow \mathrm{Od} \rightarrow \\
\mathrm{So} \rightarrow \mathrm{D} \rightarrow \\
\mathrm{Sf} \rightarrow \mathrm{Hs}\end{array}$ & $\begin{array}{c}\text { G24 } \\
\text { G25-27 }\end{array}$ & $\begin{array}{l}\text { Various shades/ colors and soft } \\
\text { surface effect }\end{array}$ & $\begin{array}{l}\text { Rinse for over } \\
\text { dyed articles }\end{array}$ & F24-27 & $\begin{array}{l}\text { To remove the } \\
\text { sizing agents } \\
\text { and unfixed dyes }\end{array}$ \\
\hline SD6 & $\begin{array}{l}\mathrm{B} \rightarrow \mathrm{Si} \rightarrow \mathrm{Ds} \rightarrow \\
\mathrm{D} \rightarrow \mathrm{Sf} \rightarrow \mathrm{Ac} \rightarrow \\
\mathrm{So} \rightarrow \mathrm{D} \rightarrow \mathrm{Sf}\end{array}$ & G31 & $\begin{array}{l}\text { Surface effects contrasting or } \\
\text { tone-in-tone }\end{array}$ & \multirow{2}{*}{$\begin{array}{l}\text { Enzyme } \\
\text { washing } \\
\text { to imitate } \\
\text { stone washing }\end{array}$} & F31 & \multirow{2}{*}{$\begin{array}{l}\text { To achieve } \\
\text { a lightly worn } \\
\text { and faded look }\end{array}$} \\
\hline $\begin{array}{l}\text { SD5 } \\
\text { SD6 } \\
\text { SD7 }\end{array}$ & $\begin{array}{l}\mathrm{B} \rightarrow \mathrm{Si} \rightarrow \\
\mathrm{So} \rightarrow \mathrm{D} \rightarrow \mathrm{Sf}\end{array}$ & $\begin{array}{c}\text { G30; } \\
\text { G32-33; } \\
\text { G34-35 }\end{array}$ & Soft surface effect & & \begin{tabular}{|c|} 
F30; \\
F32-F35
\end{tabular} & \\
\hline
\end{tabular}

* Brushing (B); Singeing (Si); Caustification (C); Drying (D); Sanforizing (Sf); Acrylic coating (Ac); Softening (So); Resin treatment (Rt); Overdyeing (Od); Heat setting (Hs); Desizing (Ds).

Choosing the appropriate testing method: as to comply with the objectives of the present work, the descriptive test was chosen to characterize quantitatively, and, by inclusion qualitatively, a number of six specific sensory attributes (bipolar attributes) of the seventy stretch denim assortments, as fabric hand descriptors $[15,18]$.

Choosing sensory assessors for the panel configuration: for this work, the approach was different from the one specified by the standards, where for a quantitative descriptive sensory analysis, a panel of selected or expert assessors is needed. Here, were recruited sixteen second year students of textile bachelor level as panellists, with a slight background in textiles and without prior taking part in sensory sessions for descriptive tests approach, called naive assessors, the nomenclature being stated within standards $[15,19]$. During the recruitment and some coaching, it was obvious that all of them had unambiguous ideas about their expectations about the sensorial comfort of any item of women clothes as wearers. This was the idea of a "fresh panel" with some background in textile, used to wearing jeans, but as naive assessors when it comes to sensory analysis.

Training procedure for the sense of fabrics tactile properties: the group of naive assessors as panellists had to get a minimum training and was coached by facilitators (three teachers) to quantify and qualify their feelings when handling the stretch denim fabrics samples. The training enabled assessors to describe the product's sensory properties by using a given glossary of hand descriptive terms and with definitions for each one of the attributes. It also enabled assessors to handle the samples in a specific way, depending on the evaluated attribute. Table 3 shows the proper actions for the evaluation of the physical attributes by means of mechanical and surface properties of the fabric, in compliance with the criteria of Kawabata and AATCC Evaluation Procedure Appendix A [14-15, 18-19].

Quantifying the intensity of sensorial perceptions during the blind handling of fabrics: as naive assessors, the sixteen students learned about the glossary of descriptive terms and the attributes to be used for the evaluation of stretch denim. Subsequently, they learned to quantify their senses' intensity during the blind handling of fabrics, by scoring each sensory feature on a common intensity scale from a score sheet. As shown in table 3, for six mechanical and surface properties, two extreme values of the related physical attributes as fabric hand descriptors, called bipolar attributes, were established. To "translate" the tactile sensations into grades, the students were taught to use a rating scale for each bipolar attribute, with grades from 1 to 10 . For example, the selected attribute "flexible" as an extreme was assigned with the grade "one" (the most flexible) while the attribute for the other extreme ("stiff") received the grade "ten" (the most non-flexible); the meaning of grade "five" was that the fabric is felt as being moderately flexible/ stiff.

Other requirements and guidelines for deploying sensorial analysis trials: before the evaluations, all the samples were preserved under the standard atmospheric conditions and each evaluation session was performed under the same experimental conditions 
HANDLING FOR THE HUMAN PERCEPTION OF FABRIC PROPERTIES RELATED TO THE FABRIC HAND

\begin{tabular}{|c|c|c|}
\hline Handling for evaluation of the mechanical & d surface properties & $\begin{array}{l}\text { Bipolar physical attributes } \\
\text { as hand descriptors }\end{array}$ \\
\hline $\begin{array}{l}\text { Tensile properties assessment: by gripping the fabric } \\
\text { between two fingertips and by stretching it in the } \\
\text { orthogonal direction from the fixed fabric edge. }\end{array}$ & & Stretchable/Non-stretchable \\
\hline $\begin{array}{l}\text { Shear properties assessment: by squeezing the fabric } \\
\text { between two fingertips and by stretching it roundtrip, } \\
\text { in the parallel direction from the fixed fabric edge. }\end{array}$ & & Soft/Hard \\
\hline $\begin{array}{l}\text { Bending properties assessment: by providing a fabric } \\
\text { fold under its own weight and by gripping the fabric } \\
\text { between two fingertips. }\end{array}$ & & Flexible/Stiff \\
\hline $\begin{array}{l}\text { Compression properties assessment: by squeezing } \\
\text { the fabric in its thickness between two fingertips } \\
\text { without any other movement }\end{array}$ & & Thin/Thick \\
\hline $\begin{array}{l}\text { Surface properties assessment: by gently squeezing } \\
\text { the fabric in its thickness between two fingertips and } \\
\text { then sliding them in the orthogonal direction from the } \\
\text { fixed fabric edge. }\end{array}$ & at & Slippery/Rough \\
\hline $\begin{array}{l}\text { Weight assessment: by providing a free fabric fold, } \\
\text { under its own weight and then lifting it with the palm } \\
\text { of the hand }\end{array}$ & & Light/Heavy \\
\hline
\end{tabular}

$[15,17]$. The assessment technique applied for this study by the individual panellists was a "blind handling" with mono-sense approaches of each fabric hand descriptor and,all evaluation sessions received support from the facilitators. The samples of the same size $(200 \mathrm{~mm} \times 200 \mathrm{~mm})$ were randomly presented one-by-one to each assessor by the facilitators, inside special boxes without visual access but only accessible to the assessors' hands. Each item was assessed within the allowed time lapse (up to 10 seconds, for each sample and for each bipolar physical attribute). The facilitators provided students the monitoring of the handling technique, guided the succession of handling step by step for every hand descriptor and completed the evaluation sheets with reported grades by panellists, as their sensorial feeling quantification during the stretch denim fabrics handling.

\section{Statistical analysis strategy for the sensory results}

The panellist's performance checking is mandatory and needed specific techniques for the statistical analysis of the results [14-15, 20-21]. This paper will present two stages as successive approaches within the statistical analysis strategy for the overall sensory analysis data reported after the stretch denim fabric hand assessment, completed with the support of the interactive ICT-based learning tools previously developed STAT-Hand (Statistical Analysis for Hand) 
and STAT-ConCor (Statistical Analysis for Concordance and Correlation) [22-24].

\section{RESULTS AND DISCUSSION}

On the sensory profiles, after the blind subjective evaluation of stretch denim fabrics hand, for the analysis of the sensorial accuracy within the panel

In the first stage, the main issue was to get an image of the overall sensorial feelings accuracy within the panel, namely whether or not the students, as naive assessors, succeeded (while blind evaluating) to perceive and to quantify the sensory differences between samples of stretch denim as greige fabrics and, afterwards, as finished fabrics.

The STAT-Hand software application allowed generating the Sensory Profiles of Fabrics (SPF), of each of the seventy stretch denims, based on the assigned grades awarded by each of the sixteen students as naive assessors (E01 $\div$ E16) when quantifying their

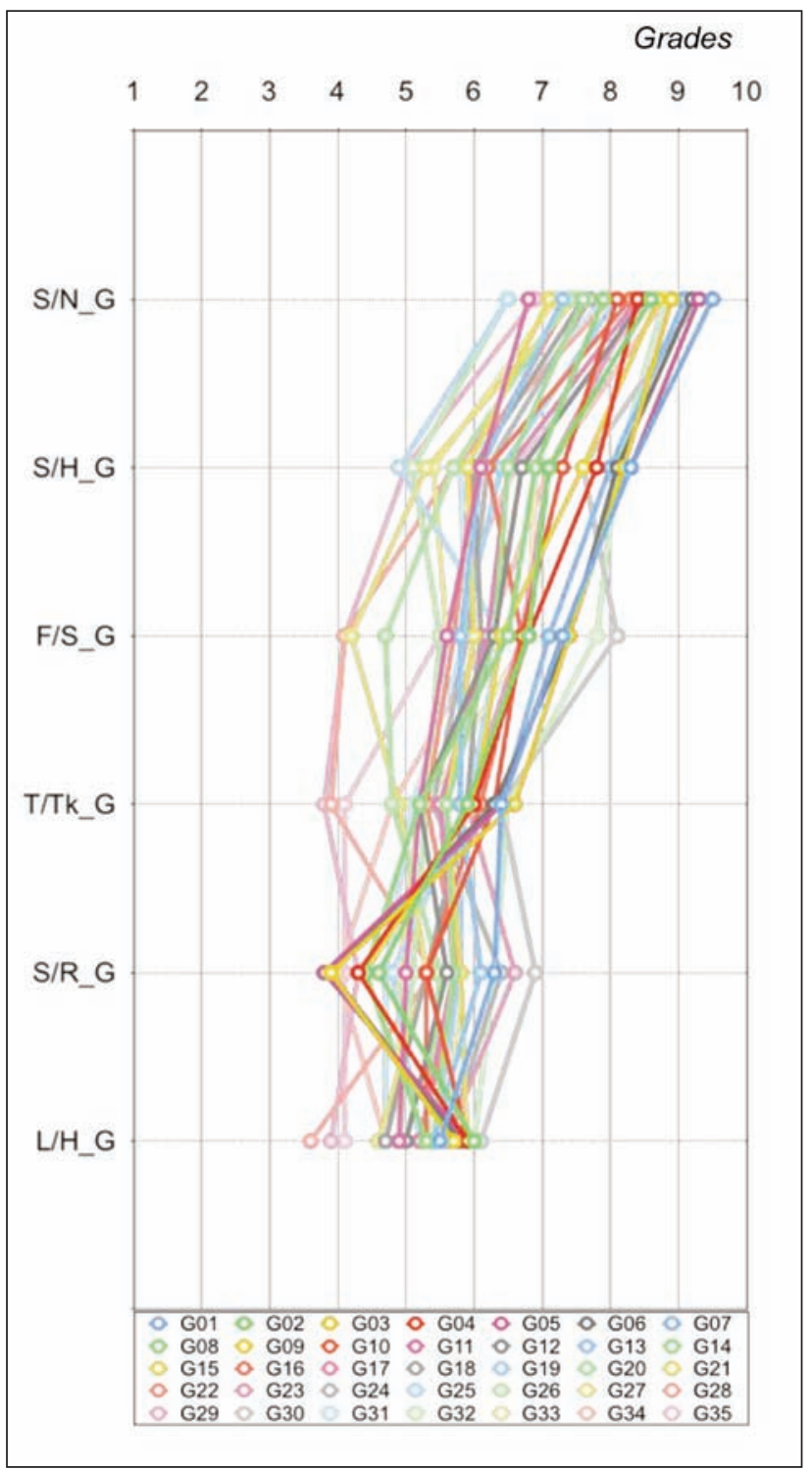

individual perceptions on the fabric hand descriptors, during the blind evaluation trials. During sensory analysis trials, a huge number of sensory profiles were obtained: an amount of 1,120 issued by sixteen evaluators for seventy fabrics, with 560 for each group of fabrics, as greige denim (G01 to G35) versus finished denim (F01 to F35). Consequently, it was considered as more useful to graphically represent the sensory profiles for the average of the ratings reported for each of the seventy stretch denim fabrics by the panellists.

Figure 1 shows the graphical representation of the average sensory profiles of seventy stretch denim fabrics after the blind evaluation, allowing a comparison in terms of similarity/dissimilarity between evaluations within the panel, considering all six bipolar attributes: stretchable/non-stretchable $(\mathrm{S} / \mathrm{N})$, soft/ hard $(S / H)$, flexible/stiff $(F / S)$, thin/thick (T/Tk), slippery/rough $(S / R)$, and light/heavy $(L / H)$.

The sensory profiles are as different as the fabrics are, remaining in a certain range of the rating scale

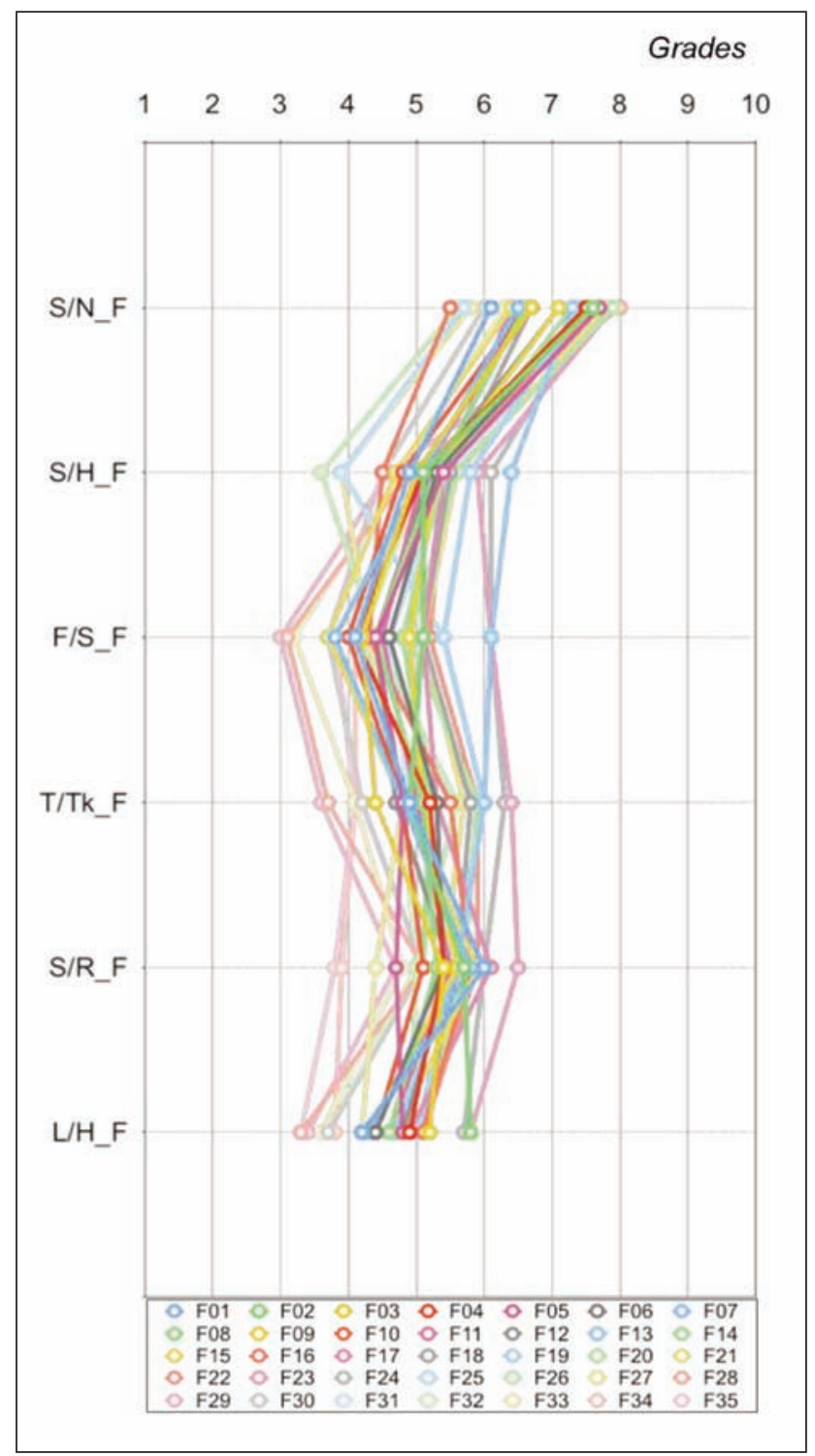

Fig. 1. Average sensory profiles generated by means blind evaluation of the stretch denims after two finishing processes: $a-$ SPF of greige denims; $b-$ SPF of finished denims 
for the entire assortment. It was obvious that there was a difference between the ways in which the hand descriptors have been perceived and reported by the panellists during handling for the two groups of fabrics, greige (after pre-finishing) and finished (after washing). Hence, during handling, the sixteen panellists felt the difference between the two fabric groups and, overall, the finished ones have each of the six bipolar attributes at a better level from the sensorial comfort point of view of the potential jeans consumers: the finished materials were felt with better elasticity, are softer, more flexible, rather thicker than thinner, and with medium level perceived smoothness and weight.

\section{On the sensory data analysis for the rating consistency evaluation within the panel of naive assessors}

The Kendall's concordance test was performed to determine if there was an agreement between the naive assessors of the entire panel, on the sensory analysis results separately reported on each sensory attribute as fabrics hand descriptor. During the blind subjective evaluation, each of the six bipolar attributes was quantified by all panellists and, to confirm the homogeneity of the panel in terms of the sensorial perceptions for which they have given grades to the same series of samples, the concordance between the assessors' judgments ought to be analysed.

The summary table 4 included the overall results of the Kendall's coefficients (W) for the greige stretch denims (G01 to G35) and finished stretch denims (F01 to F35) considering each of the six bipolar attributes: stretchable/non-stretchable, soft/hard, flexible/stiff, thin/thick, slippery/rough and light/heavy, as they were perceived by the naive assessors. In this table were also included the computed values for the statistical significance tests to prove Kendall's coefficients' statistical significance.

On a panel level, the best values of the Kendall coefficient, with moderate agreement between individuals, were obtained for bipolar attributes of the greige fabrics stretchable/non-stretchable, soft/hard and flexible/stiff. Regarding the thin/thick and slippery/ rough attributes, the values are good enough for the greige fabrics, which underline a lower to moderate agreement between individuals, and smaller values for the finished ones. Altogether, for the perception of the light/heavy bipolar attribute, the panellists seemed to be in the lowest agreement for greige and finished denims too. Following the results of the statistical significance test by comparing the computed values with the critical value $\left(\chi_{0.05 ; 34}^{2}=43.773\right)$, the coefficients of concordance came out as statistically significant at a confidence range of $95 \%$ (level of significance 0.05) for all bipolar attributes. Next to the significance test of the Kendall's coefficient of concordance, the overall situation strengthens the hypothesis that there is a convincing evidence of agreement between students as naive assessors during the blind handling evaluation of the stretch denims, with a moderate degree for more than half of the bipolar attributes, and with a lower than a middle degree for the other attributes, also depending on the finishing stage (greige or finished fabrics).

Subsequently, the initiated assessors should attend replicate sessions of sensory analysis for the seventy stretch denim fabrics, approached by a similar technique and pursuing the same tasks, as a step towards a new level of competences that shall be the selected sensory assessors' level.

\section{CONCLUSIONS}

This paper focused upon the sensory assessment of the tactile properties as descriptors of stretch denim fabric hand, for a wide range of seventy denims, evaluated after two successive finishing stages (applied in several variants), to confirm the existence of certain differences between fabrics, easy to distinguish by a panel of naive assessors, who could be usual jeans wearers. The stretch denim assortment was produced from seven articles in the loom-state phase by combining two types of right-hand twill, with $100 \%$ cotton in the warp system yarns and six mixture types in the weft system as core-spun yarns (cotton, cotton/elastane and cotton/elastane/polyester) incorporating different amounts of elastane $(1 \%, 2 \%$ and $8 \%)$

DATA ANALYSIS FOR THE RATING CONSISTENCY EVALUATION WITHIN THE PANEL OF SIXTEEN NAIVE ASSESSORS

\begin{tabular}{|c|c|c|c|c|c|c|c|c|c|c|c|}
\hline \multicolumn{12}{|c|}{ Kendall's coefficients of concordance, W } \\
\hline \multicolumn{2}{|c|}{$\begin{array}{c}\text { Stretchable/Non } \\
\text { Stretchable }\end{array}$} & \multicolumn{2}{|c|}{ Soft/Hard } & \multicolumn{2}{|c|}{ Flexible/Stiff } & \multicolumn{2}{|c|}{ Thin/Thick } & \multicolumn{2}{|c|}{ Slippery/Rough } & \multicolumn{2}{|c|}{ Light/Heavy } \\
\hline$W_{S / N G}$ & $\mathrm{~W}_{\mathrm{S} / \mathrm{N} F}$ & $W_{S / H G}$ & $\mathrm{~W}_{\mathrm{S} / \mathrm{H} \mathrm{F}}$ & $W_{F / S G}$ & $\mathrm{~W}_{\mathrm{F} / \mathrm{S} \mathrm{F}}$ & $\mathrm{W}_{\mathrm{T} / \mathrm{Tk} \mathrm{G}}$ & $\mathrm{W}_{\mathrm{T} / \mathrm{Tk} \mathrm{F}}$ & $W_{S / R G}$ & $\mathrm{~W}_{\mathrm{S} / \mathrm{R}_{-} \mathrm{F}}$ & $W_{L / H G}$ & $\mathrm{~W}_{\mathrm{L} / \mathrm{H} \mathrm{F}}$ \\
\hline 0.395 & 0.245 & 0.402 & 0.169 & 0.441 & 0.336 & 0.314 & 0.295 & 0.337 & 0.197 & 0.245 & 0.195 \\
\hline \multicolumn{12}{|c|}{ Chi-Squared Test - computed values of $\chi^{2}$} \\
\hline$X^{2} S / N \_G$ & $X^{2} S / N_{-} F$ & $X^{2} S / H \_G$ & $X^{2} S / H_{-} F$ & $\chi_{F / S \_G}^{2}$ & $\chi_{F / S+F}^{2}$ & $\chi^{2}{ }_{T / T K_{B} G}$ & $\chi_{T / T K_{F} F}^{2}$ & $\chi_{S / R \_G}^{2}$ & $\chi^{2} S / R_{-} F$ & $\chi_{L / H \_G}^{2}$ & $\chi_{L / H}^{2} \mathrm{~F}$ \\
\hline 214.8 & 133.2 & 218.7 & 91.9 & 239.9 & 182.8 & 170.8 & 160.4 & 183.3 & 107.2 & 133.2 & 106.1 \\
\hline
\end{tabular}

*The codification meaning example: $\mathrm{W}_{\mathrm{S} / \mathrm{N}_{-} \mathrm{G}}$ is the Kendall's coefficient of concordance computed for stretchable/non-stretchable bipolar attribute of the greige stretch denim. 
and polyester $(7 \%, 13 \%$ and $22 \%)$, subjected to six industrial pre-finishing processes and, subsequently, to four washing techniques.

The main findings following the statistical analysis of the sensory results should support the usefulness of the subject for the stretch denim fabrics producers, which now stand for a significant percentage of the global denim market. The sensory profiles allowed a comparison in terms of similarity/dissimilarity between evaluations within the panel, for all samples and considering all six bipolar attributes. Within the panel of naive assessors, the overall sensorial feelings accuracy during the blind subjective evaluation was good enough, since the difference between the two groups of fabrics (greige versus finished) was revealed by means of the sensory profiles. Subsequently, the Kendall's coefficients of concordances were convincing evidence of a moderate agreement between students as naive assessors, during the blind handling evaluation of stretch denim fabrics with multiple applied finishing and washing techniques.

This research was an attempt to suggest the idea that the need to feel the fabrics is self-understood for any buyer of clothing items, regardless whether they have a background in textile or not, or training in sensory analysis. For producers, it should be obvious that the naive assessors and, moreover, the untrained consumers' feelings about the fabric' sensorial comfort, could also be significant for a successful garment on the market.

As future work, the authors intend to conduct sensory evaluation sessions with potential wearers of special textile products, as features and destination, classified as smart textiles. Smart prototypes will be developed within the Skills4Smartex project and the panels of assessors will be made up of VET students, participants in the project activities. Both their training and the improvement of their skills of subjectively evaluating the intelligent textile products obtained in the project will be approached.

\section{ACKNOWLEDGEMENTS}

The authors would like to thank the management of UCO TESATURA Co. part of UCO RAYMOND Denim group for supplying the stretch denim fabrics, as well to acknowledge the support of the EC Programme Erasmus+, Project SKILLS4SMARTEX (no. 2018-1-RO01-KA202-049110).

\section{BIBLIOGRAPHY}

[1] ***Euromonitor International. Consumer Lifestyles in 2017: Global Survey Results, https://go.euromonitor.com (accessed December 2018).

[2] ***Global Denim Market Analysis and Forecast to 2023, (accessed April 2018).

[3] Harpa, R., Visileanu, E., From fabric design to the dress manufacturing, considering the fabric's suitability with the end use, In: Industria Textilă, 2018, 69, pp. 434-439

[4] Halleb, N.A., Sahnoun, M., Cheikhrouhou, M., The effect of washing treatments on the sensory properties of denim fabric, In: Text Res J, 2015, 85, 2, pp. 150-159

[5] Piroi, C., Harpa, R., Oprea, M., Regarding the effect of finishing processes on some properties of stretch denim fabrics, In: Aegean International Textile and Advanced Engineering Conference. IOP Conf. Series: Mater. Sci. Eng., 2018, 459012059

[6] Gengler, I., When People Are The Instrument: Sensory Evaluation Methods, In: ASQ Statistics division newsletter, 2009, 27-4 (accessed January 2018)

[7] Schacher, L., Bensaid, S., El-Ghezal, J., et al., Sensory and Physiological Issues, In: Vassiliadis, S., (Ed) Advances in Modern Woven Fabrics Technology. IntechOpen, 2011

[8] Naima, H.A., Mehdi, S., and Morched, C.H., Training and Control of Performance of a Tactile Sensory Panel., In: Journal of Applied Sciences, 2013, 13, pp. 366-376

[9] Harpa, R., Piroi, C., Blaga, M., Sensory analysis: approach for total handle evaluation of wool-type fabrics. In: IOP Conf. Ser.: Mater. Sci. Eng., 2019, 459. 012045

[10] Valatkienè, L., Strazdienè, E., Accuracy and Reliability of Fabric's Hand Subjective Evaluation, In: Mater. Sci. (Medžiagotyra), 2006, 12, pp. 253-257

[11] Melkie, G.T., Harpa, R., et al., Assessing the comfort of functional fabrics for smart clothing using subjective evaluation, In: J Ind Text, 2019, 48, 8, pp. 1310-1326

[12] ISO 20613:2019. Sensory analysis - General guidance for the application of sensory analysis in quality control

[13] Kanai, H., Morishima, M., Nasu, K., et al., Identification of principal factors of fabric aesthetics by the evaluation from experts on textiles and from untrained consumers, In: Text Res J, 2011, 81, 12, pp. 1216-1225

[14] AATCC EP 5:2011. Fabric Hand: Guidelines for the Subjective Evaluation of, In: AATCC Technical Manual, pp. 388-390

[15] ISO 6658: 2017. Sensory analysis - Methodology - General guidance

[16] ISO 5492:2009. Sensory analysis - Vocabulary

[17] ISO 8589:2017. Sensory analysis - General guidance for the design of test rooms 
[18] ISO 11035:2015. Sensory analysis - Identification and selection of descriptors for establishing a sensory profile by a multidimensional approach

[19] ISO 8586:2014. Sensory analysis - General guidelines for the selection, training and monitoring of selected assessors and expert sensory assessors

[20] ISO 11132:2012. Sensory analysis - Methodology - Guidelines for monitoring the performance of a quantitative sensory panel

[21] ISO 13299:2016. Sensory analysis - Methodology - General guidance for establishing a sensory profile.

[22] Bona M., Statistical methods for the Textile Industry. Eurotex-Textilia, 1993

[23] Harpa, R., Fabric Hand: Approach by Means of Software Package for Teaching Students. Part II - Software Applications, In: 12th Int. Scientific Conf. on eLearning and Software for Education(edRoceanu I), 2016, 3, pp. 518-525

[24] Harpa, R., Cristian, I., Piroi, C., STAT-CONCOR: Software for Validating the Panel of Assessors, Subsequently to the Fabric Hand Evaluation, In: 13th Int. Scientific Conf. on eLearning and Software for Education(edRoceanu I), 2017, 3, pp. 431-438

\section{Authors:}

\section{RODICA HARPA ${ }^{1}$, CRISTINA PIROI ${ }^{1}$, IRINA CRISTIAN ${ }^{1}$, EMILIA VISILEANU², MIRELA BLAGA ${ }^{1}$}

1"Gheorghe Asachi” Technical University of Iasi, Faculty of Industrial Design and Business Management, Textile Engineering and Design Department, 29 D. Mangeron Blvd., 700050, Iasi, Romania

$$
\text { e-mail: rharpa@tex.tuiasi.ro }
$$

${ }^{2}$ INCDTP - The Research-Development National Institute for Textiles and Leather,

16 Lucrețiu Pătrășcanu Street, 030508, Bucharest, Romania

e-mail: office@incdtp.ro

Corresponding author:

\section{RODICA HARPA}

e-mail: rharpa@tex.tuiasi.ro 